УДК

ВАДИМ ЛУНЯЧЕК, доктор педагогічних наук, професор, завідувач кафедри креативної педагогіки і інтелектуальної власності,

Українська інженерно-педагогічна академія, Україна

ORCID 0000-0002-4412-7068

e-mail:vel2003@ukr.net

ЛІНА ІГНАТЕНКО, старший викладач, кафедра іноземних мов,

Харківський регіональний інститут державного управління

Національної академії державного управління, Україна

ORCID 0000-0002-1628-1244

e-mail:linaign8@gmail.com

\title{
ПІДВИЩЕННЯ КВАЛІФІКАЦІЇ ПРАЦІВНИКІВ СИСТЕМИ ВИЩОЇ ОСВІТИ В УМОВАХ ГЛОБАЛІЗАЩІЇ
}

VADYM LUNIACHEK,Doctor of Pedagogics, Professor, Head of CreativePedagogics and Intellectual Property Department of theUkrainian Engineering and Pedagogics Academy, Ukraine LINA IGNATENKO, Senior Lecturer of Foreign Languages Department of Kharkiv Regional Institute of Public Administration of the National Academy of Public Administration, Ukraine

\section{PROFESSIONAL DEVELOPMENT OF HIGHER EDUCATION TEACHING STAFF IN THE CONTEXT OF GLOBALIZATION}

\begin{abstract}
У роботі на засадах компаративістського підходу розглянуто процеси підвищення кваліфікації викладачів зарубіжних університетів в умовах глобалізаційних викликів. Акцент зроблено на тому, що такі процеси поставили на порядок дений питання поліпшення якості надання освітніх послуг для професійного розвитку науково-педагогічних працівників. Автором на основі аналізу інформації з електронних джерел, зокрема ВЕБ-сайтів провідних університетів світу зроблені висновки щодо подальшої модернізації системи підвищення кваліфікації науково-педагогічних працівників в Україні.
\end{abstract}

Ключові слова: викладач вищої школи, зарубіжний досвід, науковопедагогічний працівник, підвищення кваліфікації, професійний розвиток, університет.

Summary. The article presents a comparative study of the processes of professional development of faculty of foreign universities in the context of globalization challenges. Emphasis is

( ) В. Лунячек, Л. Ігнатенко placed on the fact that the processes of globalization of higher education have put on the agenda the issue of improving the quality of educational services. An important component of this process is professional development of research and teaching staff, who, to a large extent, are the guarantors of quality higher education in any country.

The paper offers an analysis of information from electronic sources, in particular, websites of the world's leading universities which allows to make conclusions on further modernization of the system of professional development of research and teaching staff in Ukraine.

Key words: lecturer, foreign experience, research and teaching staff, advanced in-service training, professional development, university.

Мета: проаналізувати аналітичні i наукові матеріали 3 професійного розвитку викладачів зарубіжних коледжів та університетів задля надання відповідних рекомендацій щодо подальшої модернізації системи підвищення кваліфікації науково-педагогічних працівників в Україні.
Постановка проблеми в загальному вигляді. Процеси глобалізації вищої освіти поставили на порядок денний питання поліпшення якості надання освітніх послуг. Важливою складовою цього процесу є професійний розвиток науково-педагогічних працівників, які є значною мірою гарантами надання якісної вищої освіти в будь-якій країні. Додаткової актуальності в Україні це питання набуло після вступу в дію Закону України "Про освіту" від 05.09.2017 p. № 2145-VIII та Постанови КМУ № 800 від 19.08.2019 р. "Деякі питання підвищення кваліфікації педагогічних і науково-педагогічних працівників", які фактично закріпили на нормативноправовому рівні нові підходи до підвищення кваліфікації науково-педагогічних працівників на засадах диверсифікації (Деякі питання.., URL: https://zakon.rada.gov.ua/laws/show/ 800-2019-\%D0\%BF; Про освіту.., URL : http://ru.osvita.ua/legislation/ law/2231/). Ці зміни поставили на порядок денний вивчення відповідного зарубіжного досвіду та його трансформації в українських реаліях.

Аналіз досліджень і публікацій. 
Історію та методологію порівняльнопедагогічного вивчення проблеми грунтовно розглядає ув своїх роботах О. Локшина, зокрема, підходить до генези педагогічної компаративістики в зарубіжжі, прослідковує трансформацію її методологічних постулатів тощо (Локиина, 2014).

Професійний розвиток науковопедагогічних працівників ми розглядаємо як складову частину освіти дорослих. Сьогодні в переважній більшості англомовних країн використовується термін професійний розвиток (professional development). На наявність термінологічних проблем у цій царині вказує Н. Постригач, котра на прикладі післядипломної освіти вчителів у зарубіжних країнах наголошує, що замість поняття підвищення кваліфікації, що використовується в вітчизняній літературі, та англомовного - професійний розвиток, у німецькомовних державах застосовують, наприклад, термін продовжена освіта вчителів і подальша освіта вчителів (Постригач, 2013).

О. Теренко вказує, що глобалізація та інтеграція зумовили потребу запровадження концепції освіти впродовж життя, згідно з якою освіта дорослих (ОД) є важливим чинником суспільного розвитку та підготовки висококваліфікованих фахівців (Teренко, 2018).

О. Іонова пише, що наприкінці 90х рр. минулого ст. в деяких європейських країнах (Великій Британії, Нідерландах, Німеччині та ін.) започатковано програму, спрямовану на зміну підходів до ОД, - New Adult Learning Movement (NALM) - pух за оновлення освіти дорослих. Сьогодні її реалізують у багатьох європейських країнах та Північній Америці. Засновником програми NALM є Конрад ван Хойтен - голландський учений, соціолог, педагог, визнаний у Свропі фахівець 3 оптимізації організації навчання дорослих (Іонова, 2018).

А. Кошель розглядає закордонний досвід підвищення кваліфікації працівників ЗВО як засіб підвищення міжнародної конкурентоздатності провідних університетів. Він указує, що в більшості закордонних ЗВО підвищення професійної кваліфікації враховується як позитивний фактор під час підписання контракту або зарахування на посаду після випробувального терміну, подовженні контракту, призначенні на більш високу посаду тощо. При цьому іноземні ЗВО максимально сприяють профес- ійному розвитку працівників. У багатьох 3 них існує система надання працівникам рекомендацій щодо вибору напрямів підвищення кваліфікації (Кошель, 2017).

Суттєвим надбанням є результати дослідження Девіда А. Уоткінса та Яна Ван Ааласта, які декілька десятиліть досліджували, як відбувається процес навчання в різних культурах (Исследования по сравнительному.., 2015, c. 316).

Інститут ЮНЕСКО 3 навчання протягом життя (UNESCO Institute for Lifelong Learning (UIL)) - один із семи освітніх інститугів ЮНЕСКО. Він просуває політику та практику навчання протягом життя, особливу увагу приділяє навчанню дорослих, грамотності й неформальній освіті, видає міжнародний журнал порівняльної освіти "International Review of Education - Journal of Lifelong Learning" (UNESCO Institute for Lifelong Learning, URL : https:// uil.unesco.org/).

Деякі проблеми розвитку освітньої системи України в контексті, що розглядається, висвітлені нами в попередніх роботах (Лунячек, 2017; Lunyachek, 2011; Lunyachek, 2017).

Виклад основного матеріалу дослідження. Переходячи до викладу матеріалу, наголосимо, що в його основі лежить аналіз інформації, оприлюдненої на Web-сайтах провідних університетів світу та інших організацій, що розглядають питання професійного розвитку працівників вищої освіти в зарубіжних країнах.

Провідну роль у координації шляхів розвитку вищої освіти в США, що зазначено нами в попередніх роботах, мають такі недержавні організації, як Американська асоціація вищої освіти (American Association of Higher Education), Асоціація американських коледжів і університетів (Association of American Colleges and Universities) та ін. (Лунячек, 2009). Саме вони спільно з керівництвом ЗВО формують політику професійного розвитку викладачів університетів і коледжів (Annual Report, URL : http://bit.do/fF2bT).

Структурна модель системи професійної підготовки, перепідготовки та підвищення кваліфікації викладачів вищої школи у США представлена в роботі Н. Варги. Зазначена модель охоплює всі етапи підготовки і підвищення кваліфікації викладача вищої школи США, починаючи з допрофесійної підготовки, здобуття науково- го ступеня доктора філософії або аналогічного, діяльність на посаді асистента викладача та відповідно постдисертаційний період, що передбачає участь у національних, міжуніверситетських і внутрішньоуніверситетських програмах удосконалення педагогічної майстерності (Варга, 2019).

Зазначені програми перетворилися, з точки зору Н. Приходькіної, на певний рух, що направлений на розвиток професорсько-викладацького складу. У його основі об?єктивні причини: недоліки у традиційному викладанні, зокрема, відсутність у викладачів формальної підготовки в галузі методики викладання, несформованість професійно-комунікативної компетенції, а також розширення і зміна потреб студентського контингенту (Приходькіна, 2013). Окремо слід зупинитися на формуванні портфоліо викладача. Так, Я. Бельмаз пише, що це один з провідних методів професійного розвитку в американській і британській педагогічній практиці для документації професійних досягнень. Портфоліо дає змогу викладачеві визначити для себе шлях професійного розвитку (Бельмаз, 2011).

Проведений нами аналіз підтвердив, що система підвищення кваліфікації викладачів у Сполучених Штатах Америки забезпечується як за рахунок можливостей самого навчального закладу, так і шляхом навчання за його межами. Сьогодні майже в кожному коледжі або університеті США існує Центр підвищення кваліфікації викладачів Centre for Teaching and Learning (CTL). Наприклад, Centre for Teaching and Learning (CTL) Стенфордського університету пропонує педагогічну підтримку як окремим викладачам, так і цілим кафедрам. Він пропонує як заздалегідь заплановані курси, так і курси за запитом, а також різні форми експертного консультування, електронні ресурси та платформи для залучення учнів і підвищення ефективності навчання в аудиторіях та поза їх межами. Центр є відкритим для кожного, хто викладає у Стенфорді, займається формуванням освітніх програм, працює зі студенською громадою або опікується адміністративною діяльністю. Також SCTE має великий досвід партнерства з кафедрами та центрами підвищення кваліфікації інших навчальних закладів. (Stanford. Center for Teaching and Learning (CTL). URL : https:// 
ctl.stanford.edu/).

Колумбійський університет також має сталі традиції забезпечення можливостей професійного розвитку викладачів. Місією Центру викладання та навчання (CTL) Колумбійського університету є співпраця з викладачами, студентами та колегами в університеті, щоб підтримати майстерність та інновації у викладанні і навчанні. Своїми програмами, послугами та ресурсами CTL прагне вдосконалити культуру викладання і навчання в Колумбійському університеті, приділяє велику увагу не тільки практичній педагогічній діяльності, але й дослідженням у галузі вдосконалення інструментів викладання та адміністрування. У 2018 р. на щорічному Симпозіумі, який проводить Центр викладання та навчання (CTL) Колумбійського університету, офіційно оголошено про започаткування Ініціативи Science Of Learning Research (SOLER) - Дослідження в галузі педагогіки, у межах цієї ініціативи CTL університету став центром міждисциплінарних досліджень і стипендіальних программ (Columbia university. Center for Teaching and Learning (CTL). URL : https:// ctl.columbia.edu/).

Також існує програма мінігрантів "StartSmall!", які доступні викладачам, що мають на меті проведення педагогічного експерименту з однією новою педагогічною стратегією чи інструментом. Так викладач отримує методичну підтримку CTL та грант до 2000 доларів за один семестр (Annual Report, URL : http://bit.do/ $f F 2 b T)$.

Розвиток системи підвищення кваліфікації в ЗВО Канади бере свій початок у 60 і 70-х роках минулого ст., коли суто індивідуальна відповідальність викладача за професійний рівень змінилася відповідальністю самих закладів за створення належних можливостей шляхом запровадження великої кількості центрів розвитку кваліфікації на кампусах коледжів та університетів (Centra, 1989; Donald, 1976). 3 того часу система професійного розвитку збагатилася новими формами і підходами, набула нових уніфікованих характеристик. У більшості коледжів та університетів обов'язки $з$ підвищення кваліфікації викладачів розподілено між центральним департаментом та окремими факультетами або кафедрами. Як показує аналіз сайтів провідних навчальних закладів Канади, центральний підрозділ відповідає за загальноінституційні програми, часто зосереджуючись на розвитку основних навичок викладання і дослідницької діяльності, що розроблені для задоволення потреби закладу освіти в цілому. Наприклад, в одному з провідних технічних університетів Канади Університеті Ватерлоо (University of Waterloo) існує Центр викладацької майстерності (The Centre for Teaching Excellence), який працює 3 окремими викладачами, кафедрами та академічними підрозділами для розвитку потенціалу викладацької спільноти, пропаганди інституційної культури (The University of Waterloo. Center for Teaching Exellence. URL: https://uwaterloo.ca/centre-forteaching-excellence/). Центр проводить навчання для викладачів-початківців 3 наданням Сертифіката університетського викладання (CUT). Програма CUT допомагає розширити знання щодо викладання і навчання; створити середовище, у якому обговорюватимуться питання викладання; розвивати навички, які готують конкурувати на сучасному ринку праці. Наявність такого сертифіката береться до уваги при укладанні контракту з молодим викладачем та зараховується за досвід викладання.

Прикладом структури, створеної для підвищення кваліфікації професорсько-викладацького складу на рівні факультету, Центр безперервного професійного розвитку (Continuing Professional Development - CPD), що існує на медичному факультеті Університету Торонто (The University of Toronto. Faculty of Medicine. Faculty Development. URL https://www.cpd.utoronto.ca/ educators/faculty-development/).

Професійний розвиток викладачів вищої школи у Великій Британії регламентується Національною рамкою професійних стандартів для викладачів вищої освіти Великої Британії (2011 p.) (The UK Professional.., 2011). О. Мельникова акцентує на відсутності в цій країні законодавчо встановлених вимог організації навчання на курсах професійного розвитку викладачів вищої школи і критеріїв зростання їх професійної компетентності, оскільки за це відповідають університети, більшість яких має свої центри, відділи, що опікуються професійним розвитком персоналу (Мельникова, URL : http:// enpuir.npu.edu.ua/bitstream/ 123456789/4763/1/Melnykova.pdf).
Проведене нами дослідження свідчить, що програми професійного розвитку, спрямовані на підвищення якості викладання, були звичною складовою вищої освіти Великобританії протягом багатьох років. Понад 80 відсотків британських університетів вимагають від академічного персоналу інформації про підвищення професійної кваліфікації. Постійно зростають очікування як від нових, так і від досвідчених викладачів щодо наявності додаткових кваліфікаційних сертифікатів, участі у стипендіальних програмах удосконалення педагогічної майстерності.

На сайті Інституту педагогічних досліджень, що входить до структури Плімутського університету, професійний розвиток упродовж життя (continuing professional development (CPD)) визначається як "будь-яка діяльність, спрямована на зміцнення та розширення знань, умінь й уявлень викладачів таким чином, що приводить до змін у їхньому мисленні та їхній навчальній поведінці" (University of Plymout. URL : https:// www.plymouth.ac.uk/research/ institutes/pedagogic/cpd.). Це може включати сертифікаційні програми Сертифікат післядипломної освіти або менш формалізовані заходи (участь у професійних дискусійних групах та неофіційне менторське партнерство). Національне опитування, проведене в рамках дослідницького проєкту Інституту педагогічних досліджень, показало, що найбільш поширеними в ЗВО Великобританії $\epsilon$ такі заходи $з$ підвищення кваліфікації:

- акредитовані курси 3 наданням сертифікату (сертифікат післядипломної освіти в академічній практиці);

- семінари, спрямовані на певні теми, пов?язані з навчанням;

- навчально-методичні конференції та семінари;

- внутрішні схеми акредитації викладання в межах 3ВО;

- експертна оцінка викладання;

- міні-гранти на відвідання зовнішніх навчальних курсів.

Як ми наголошували вище, усі програми професійного розвитку побудовано відповідно до вимог Рамки професійних стандартів Великої Британії(UKPSF), що надає опис діапазону діяльності, знань і цінностей, які очікуються від того, хто навчає або забезпечує процес навчання, та містить перелік об'єктивних критеріїв, 
3 гідно 3 якими можна визначати, чи досягнуто стандарт у професійній діяльності викладача. Рамка професійних стандартів PSF може бути застосована до програм особистого розвитку на індивідуальному, інституційному чи національному рівнях для підвищення якості викладання і визначення його результатів (The UK Professional Standards Framework for teaching and supporting learning in higher education (2011). URL : http://bit.do/fF2cY).

Головною інституцією, що опікується забезпеченням сталого професійного розвитку академічних працівників, є Академія вищої освіти (нова назва AdvanceHigherEducation) (Advance Higher Education. URL: http://bit.do/fF2bQ.). Завдяки низці міжнародних угод вона сприяє вдосконаленню професійної кваліфікації працівників вищої школи далеко за межами Сполученого Королівства. Станом на грудень 2019 року Академією вищої освіти акредитовані програми професійного розвитку викладачів ЗВО в понад 125 установах у всьому світі.

У всіх провідних ЗВО Великої Британіі функціонують окремі підрозділи, що відповідають за підвищення професійного рівня за трьома головними напрямами - технології освіти, дослідницька діяльність, адміністрування освітніх процесів. Так, у Кембріджі є Центр викладання та навчання (CTL), метою діяльності якого передбачається підтримка освітян, заохочення інновацій та підвищення рівня освіти в Кембриджі. Центр пропонує як довгострокові сертифікаційні курси, так і короткотермінові семінари і консультації (Cambridge Center for Teaching and Learning. URL : https://www.cctl.cam.ac.uk/aboutcctl). Креативні проекти реалізуються також Оксфордським інститутом начання (The Oxford Learning Institute) (The Oxford Learning Institute. URL : https:// pod.admin.ox.ac.uk/oxford-learninginstitute-change.).

ЗВО Австралії наслідують досвід Великої Британії. Нещодавно Сіднейський університет став стратегічним партнером Академії вищої освіти (HЕA), що дозволяє подати свої програми професійного розвитку для акредитації HEA та започаткування певних стипендіальних програм. Акредитовані НЕА програми та стипендії узгоджуються з Рамкою професійних стандартів. Університет
Сіднея приєднався до дев?яти інших установ Австралії, партнерів НЕА. Для забезпечення контролю над програмами та заходами Академії вищої освіти в Австралії створена Стратегічна консультативна рада, що координує програми професійного розвитку у ЗВО Австралії та Нової Зеландії, реалізацією яких займаються Центри професійної освіти в місцевих університетах і коледжах (The University of Sydney becomes an HEA Strategic Partner. URL : http://bit.do/fF2c4).

Розглядаючи професійний розвиток викладачів вищої школи в Німеччині, озвучимо позицію С. Благініної, яка пише, що чи не єдиний динамічний сектор вищої освіти в цій країні це сектор вищої професійної освіти, який включає так звані вищі фахові школи (Fachhochschulen). Однак дослідниця наголошує на розриві в навчальних вимогах до професорів університетів та ін. колег, які керують кафедрами у вищих фахових школах (Благініна, 2017). Т. Горохівська, посилаючись на численні зарубіжні джерела, пише, що розвиток професійно-педагогічної компетентності викладачів у Німеччині відбувається за двома напрямами: підвищення кваліфікації педагогів ("Lehrerforbildung") - підвищення професійної компетентності викладачів до впровадження інновацій в освітній процес, застосування сучасних методів навчання і виховання, збагачення знань та практичних умінь 3 педагогіки, методики викладання дисциплін, психології тощо; додаткова підготовка педагогів ("Lehrerweiterbildung") - отримання нової або розширення базової професійної кваліфікації (Горохівська, 2019).

На наше переконання, систему підвищення кваліфікації викладачів вищої школи в Німеччині доцільно розглянути на прикладі центру HDW NRW - об'єднання університетів землі Північний Рейн-Вестфалія. 3 2009 р. співпраця між університетами регулюється Угодою, що перебачає дворівневу модель співпраці, систему сертифікації та необмежений термін існування межвузівської мережі. Міжвузівський центр підвищення кваліфікації сприяє наданню дидактичної підтримки та розвитку професійних навичок викладачів вищої школи і наукових співробітників, що працюють на базі університетів.

Програма безперервної освіти мережі HDW NRW призначена для всіх, хто відповідає за навчання в 20 університетах-членах. Крім того, багато пропозицій відкриті для зовнішніх учасників і університетів. Зовнішні учасники - викладачі університетів, котрі не входять в це об'єднання, мають сплатити більш високу вартість за участь.

Навчальний центр пропонує навчання за різними професійними напрямами. Для обміну досвідом між колегами, ініціювання спільних міжуніверситетських проєктів і професійного, і дидактичного розвитку центр пропонує різні робочі групи, які відкриті для всіх осіб, що пов'язані 3 процесом навчання незалежно від того, чи це викладач-початківець, чи досвідчений професор. За результатами професійного навчання учасники отримують сертифікати. Навчання є комбінацією очних семінарів, письмових робіт та створення власного портфоліо (https:// www.hdw-nrw.de/).

Аналізуючи систему підвищення кваліфікації викладачів вищої школи у Франції, слід наголосити, що, починаючи з вересня 2019 р., такий процес тут здійснюється в межах Вищих Національних Інститутів працівників Освіти та Навчання (Instituts Nationaux Superieurs du Professorat et de l'Education). Інститути є структурними підрозділами університетів та академій. Завдяки спільній співпраці 3 університетами підвищення кваліфікації переважно здійснюється в реальних умовах на робочому місті. До складу мережі Вищих Національних Інститутів працівників Освіти та Навчання входять 32 інститути і Вища національна Школа освіти та навчання в галузі сільського господарства (L'annuaire des INSPE. URL : http:// bit.do/fF2cu.). Навчання здійснюється на основі компетентнісного підходу. Особлива увага приділяється проведенню досліджень, написанню наукових робіт (Le Reseau National Des ESPE Devient Le Reseau Des INSPE. URL : http://www.reseau-espe.fr/). Пeдагогічна освіта у Франції - це безперервний процес у межах Концепції навчання протягом життя. Викладачі постійно проходять курси підвищення кваліфікації, після яких складають іспити. У разі успішної здачі іспитів відбувається індексація заробітної плати.

Серед країн Далекого Сходу варто звернути увагу на досвід Китаю, який у ХХ ст. будував систему вищої освіти, виходячи $з$ досвіду СРСР, що 
знайшло своє відображення і в системі підвищення кваліфікації працівників 3ВО. Водночас з початку XXI ст. у КНР розпочалася суттєва трансформація системи вищої освіти як результат глобалізаційних процесів у цій сфері. Характерною особливістю Китаю $є$ те, що в більшості випадків навчальні заходи для викладачів організовані відповідно до доктрин вищих державних органів влади (Mohrman, Geng \& Wang, URL : http:/ /www.nea.org/assets/docs/HE/HMohrman_28Feb11_p83 - 100.pdf.). Підхід, який відповідав всім принципам, що пропагувала влада, мав досить формальний характер і реалізовувався без урахування індивідуальних потреб викладачів або специфічних запитів того чи іншого закладу освіти (Lin \& Wu, 2011).

У китайському контексті дослідження шляхів розвитку професійного рівня професорсько-викладацького складу розпочалися лише нещодавно (Li B., Li K. \& Pu, 2012). Ураховуючи високі вимоги до підвищення кваліфікації та оновлення знань у сучасному освітньому середовищі, темпи та рівень програм професійної підготовки не відповідали очікуванням викладачів студентів. Перелам настав на початку XXI ст., коли у КНР відбулася суттєва трансформація системи вищої освіти. Чжан Лун у своєму дисертаційному дослідженні пише, що в Китаї на межі тисячоліть прийняті певні нормативні документи, що стосувалися розвитку освіти у країні, зокрема, ще в 1999 р. - "Пропозиції щодо посилення побудови системи підготовки викладацьких кадрів вузів на новому етапі" та ін. (Чжан Лун, 2017).

В одному з найстаріших ЗВО Китаю - Пекінському педагогічному університеті (Beijing Normal University) - 2004 р. створений Інститут освіти викладачів (Faculty of Education Beijing Normal University. Institute for Teacher Education. URL : https://fe.english.bnu.edu.cn/t003-c1-52.htm). Він складається з чотирьох науково-дослідницьких відділів: історія та теорія освіти; адміністрування та політика в галузі освіти; педагогіка вищої освіти; лідерство в освіті та підвищення кваліфікації викладачів вищої школи.

Інститут зосереджується на дослідженні педагогічної освіти та професійного розвитку викладачів вищої школи. Він став центром досліджень, професійного розвитку та міжнарод- ної співпраці викладачів шляхом створення гнучких, відкритих, ефективних дослідницьких процесів, обєднання дослідників різних дисциплін та установ. 3 часу свого заснування ним здійснено понад 10 національних науково-дослідницьких проєктів і понад 70 проєктів для Міністерства освіти та муніципального уряду Пекіну.

Разом $з$ тим В. Кузнецова та ін. дослідники пишуть, що в КНР зараз існує два центри перепідготовки викладчів вищої школи на загальнонаціональному рівні, 6 - на регіональному, 31 - провінціальному. Автор наголошує, що ця багаторівнева мережа не може вирішити проблему якісної перепідготовки кадрів (Кузнециовa, 2009).

Висновки та перспективи подальших досліджень. Отже, диверсифікація процесів підвищення кваліфікації науково-педагогічних кадрів в Україні стимулювала наукові пошуки відповідного досвіду у провідних університетах світу як взірця для розробки відповідних підходів на національному рівні.

Також вимогою часу є створення загальнонаціонального координаційного центру для регулювання процесів підвищення кваліфікації науково-педагогічних працівників ЗВО та відповідного потужного Web-порталу як одного з ключових інструментів надання необхідної інформації споживачам освітніх послуг.

В Україні повинна бути започаткована практика національних грантів для професійного розвитку викладачів університетів, яка сьогодні $\epsilon$ мало поширеною. Важливим аспектом поліпшення роботи з підвищення кваліфікації $є$ проведення низки опитувань серед викладачів 3ВО для уточнення їх професійних потреб i прийняття на цій основі відповідальних управлінських рішень. Водночас потребою часу вважаємо створення системи пролоногованого оцінювання діяльності викладчів ЗВО з урахування поліпшення їх професійної компетентності у процесі підвищення кваліфікації, що має знайти своє відображення у відповідних електронних портфоліо, що оприлюднені в Інтернет-просторі. Удосконалення потребує і система онлайн підвищення кваліфікації викладчів ЗВО узвязку з викликами сучасного етапу розвитку людства.

Перспективним напрямом нам бачиться розроблення оновленої моделі підвищення кваліфікації пра- цівників закладів вищої освіти, виходячи 3 положень Закону України "Про освіту" та досвіду провідних університетів світу.

\section{СПИСОК ЛІТЕРАТУРИ}

Бельмаз, Я. (2011). Особливості професійного розвитку викладачів вищої школи у Великій Британії та США. Порівняльно-педагогічні cmудіï, 3-4. Взято з file:///C:/Users/ Vadim\%20Lunyachek/Downloads/ 18624-27891-1-SM.pdf

Благініна, С. (2017). 3 досвіду Німеччини: забезпечення якості освіти в минулому і в наш час. Вищза школа, 9, 87-100.

Варга, Н. І. (2019). Організаційні засади професійної підготовки викладача вищої школи США. Науковий вісник Ужгородського університе$m y, 2$. Взято 3 http://bit.do/fFZ85.

Горохівська, Т. М. (2019). Зарубіжний досвід підвищення кваліфікації викладачів вищої школи як форми розвитку їх професійно-педагогічної компетентності. Науковий вісник Льотної академії, 5. Взято з file:///C:/ Users/Vadim \% 20 Lun yachek/ Downloads/sbfasps_2019_5_47.pdf.

Деякі питання підвищення кваліфікації педагогічних і науково-педагогічних працівників. (2019). Постанова Кабінету Міністрів України № 800 від 21.08. 2019 р. Взято з https:// zakon.rada.gov.ua/laws/show/8002019-\%D0\%BF.

Іонова, О. М. (2018). Антропософськи-орієнтований підхід до освіти дорослих. Педагогіка і психологія, 4, 12-20.

Брейль, М., Адамсон, Б., Мейсон, М. (Ред.). (2015). Исследования по сравнительному образованию: подходы и методы. Луганск : ФОП Сабов А. М.

Кошель, А. С. (2017). Система повышения квалификации работников ведущих вузов как способ повышения международной конкурентоспособности: зарубежный опыт. Гуманитарные исследования в Восточной Сибири и на Дальнем Востоке, 4, 6064. Взято з http://bit.do/fFZ9x.

Кузнецова, В. В., Машкина, О. А. (2009). Высшая школа КНР: успехи, проблемы, решения. Экономика образования, 2, 64-82.

Локшина, О. (2014). Професіоналізація порівняльної педагогіки в Україні: здобутки і виклики у вимірі педагогічної компаративістики у зарубіжжі. Порівняльно-педагогічні 
cmудiï, 6, 5-12. Взято 3 https:// core.ac.uk/down load/pdf/ 32309643.pdf.

Лунячек, В. Е. (2017). Підвищення кваліфікації педагогічних працівників: тенденції в умовах глобалізації. Засоби навчальної та науково-дослідної роботи.

Лунячек, В. Е. (2009). Розвиток системи вищої освіти у США в умовах децентралізації влади. Проблеми сучасної педагогічної освіти, 21, 5, $34-46$.

Мельникова, О. О. Розвиток фахової компетентності викладачів ВН3 у системі післядипломної освіти Великої Британії. Взято 3 http:// en puir.npu.edu.ua/bitstream/ 123456789/4763/1/Melnykova.pdf.

Постригач, Н. О. (2013). Підвищення кваліфікації учителів уєвропейському регіоні: проблеми, перспективи. Психолого-педагогічні науки, 3 , 55-60.

Приходькіна, Н. (2013). Особливості професійно-педагогічної підготовки викладача вищої школи США у системі підвищення кваліфікації. Нова педагогічна думка, 3, 115-118. Взято 3 http://nbuv.gov.ua/UJRN/ Npd 2013335.

Про освіту: Закон України від 05.09.2017 p. №2145-VIII. Взято з http:/ /ru.osvita.ua/legislation/law/2231/

Теренко, О. О. (2018). Організаційно-педагогічні засади освіти дорослих у США і Канаді. Педагогіка i ncuхологія, 4, 20-27.

Чжан, Лун. (2017). Особистіснопрофесійний розвиток учителів у системі безперервної педагогічної освіти Китайської Народної Республіки. (Дис. ... канд. пед. наук). Харківський національний педагогічний університет ім. Г. С. Сковороди. Харків.

Advance Higher Education. Retrieved from http://bit.do/fF2bQ.

Annual Report. CTL. Office of the Provost. Retrieved from http://bit.do/ fF2bT.

Association of American Colleges \& Universities. Retrieved from http:// bit.do/fF2bW.

Cambridge Center for Teaching and Learning. Retreived from https:// www.cctl.cam.ac.uk/about-cctl.

Centra, J. A. (1989). Faculty evaluation and faculty development in higher education. Higher education: handbook of theory and research, $\mathrm{V}$.

Columbia university. (2020). Center for Teaching and Learning (CTL). Retrieved from https:// ctl.columbia.edu/.

Donald, J. G., Shore, B. M. (1976). Annotated index to pedagogical services in Canadian colleges and universities. Montreal : Centre for Learning and Development, McGill University.

Faculty of Education Beijing Normal University. Institute for Teacher Education. Retreived from https:// fe.english.bnu.edu.cn/t003-c-1-52.htm

L'annuaire des INSP? (Instituts Nationaux Superieurs du Professorat et de l'Education). Retrieved from http:// bit.do/fF2cu.

Le Reseau National Des ESPE Devient Le Reseau Des INSPE. Retrieved from http://www.reseauespe.fr/.

Lin, J., Wu, Y. (2011). Analysis of the needs of academic staff for professional development in regular universities and colleges and the infl uential factors: based on the survey in universities and colleges in Beijing (in Chinese). Journal of Educational Studies, 7 (3), 92-104.

Li, B., Li, K., Pu, Y. (2012). The knowledge structure of the college teachers (in Chinese). University Education Science, 4, 114-118.

Lunyachek, V. (2011). Problems of the Education System Development of Ukraine in Times of Crisis. Public policy and administration, 10 (1), 6779.

Lunyachek, V. (2017). The PostSoviet Syndrome of Ukrainian Education: Administrative Issues. Public policy and administration, 1, 81-90.

Mohrman, K., Geng, Y., Wang, Y. Faculty life in China. Retrieved from http://www.nea.org/assets/docs/HE/ H-Mohrman 28Feb11 p83 - 100.pdf.

The Oxford Learning Institute. Retrieved from https:// pod.admin.ox.ac.uk/oxford-learninginstitute-change

The University of Waterloo. Center for Teaching Exellence. Retrieved from https://uwaterloo.ca/centre-forteaching-excellence/

University of Plymout. Retrieved from https://www.plymouth.ac.uk/ research/institutes/pedagogic/cpd

The University of Sydney becomes an HEA Strategic Partner. Retrieved from http://bit.do/fF2c4

The University of Toronto. Faculty of Medicine. Faculty Development. Retrieved from https:// www.cpd.utoronto.ca/educators/ faculty-development/
UNESCO Institute for Lifelong Learning. Retrived from https:// uil.unesco.org/

Stanford. Center for Teaching and Learning (CTL). Retrived from Retrieved from https:/ctl.stanford.edu/

The UK Professional Standards Framework for teaching and supporting learning in higher education. (2011). Retrieved from http://bit.do/fF2cY

Weiterbildung fur Lehrende an Hochschulen. Retrieved from https:// www.hdw-nrw.de/

\section{REFERENCES}

Belmaz, Ya. (2011). Osoblyvosti profesiinoho rozvytku vykladachiv vyshchoi shkoly u Velykii Brytanii ta SShA. Porivnialno-pedahohichni studii, 3-4. Retrived from file://C:/ Us er s / Vadi m \% 20 Lun ya chek/ Downloads/18624-27891-1-SM.pdf $>$

Blahinina, S. (2017). Z dosvidu Nimechchyny: zabezpechennia yakosti osvity $\mathrm{v}$ mynulomu i $\mathrm{v}$ nash chas. Vyshcha shkola, 9, 87-100.

Varha, N. I. (2019). Orhanizatsiini zasady profesiinoi pidhotovky vykladacha vyshchoi shkoly SShA. Naukovyi visnyk Uzhhorodskoho universytetu, Seriia Pedahohika. Sotsialna robota, 2, 26-30. Retrieved from <http://bit.do/fFZ85>

Horokhivska, T. M. (2019). Zarubizhnyi dosvid pidvyshchennia kvalifikatsii vykladachiv vyshchoi shkoly yak formy rozvytku yikh p rofes i ino-pedahoh i ch noi kompetentnosti. Naukovyi visnyk Lotnoi akademii, 5, Retrieved from <file://C:/Users/Vadim\%20Lunyachek/ Downloads/sbfasps_2019_5 47.pdf $>$

Deiaki pytannia pidvysh $\bar{c}$ chennia kvalifikatsii pedahohichnykh i n a u k ovo-pedah oh i ch n y k h pratsivnykiv. (2019). Postanova № 800 vid 21.08.2019 roku. Kabinet Ministriv Ukrainy. Retrieved from < https:// zakon.rada.gov.ua/laws/show/8002019-\%D0\%BF>

Ionova, O. M. (2018). Antroposofsky-oriientovanyi pidkhid do osvity doroslykh. Pedahohika $i$ psykholohiia, 4, 12-20.

Brejl, M., Adamson, B., Mejson, M. (Eds.). (2015). Issledovanija po sravnitelnomu obrazovaniju: podhody i metody, Lugansk : FOP Sabov A. M.

Koshel, A. S. (2017). Sistema povyshenija kvalifikacii rabotnikov vedushhih vuzov kak sposob povyshenija mezhdunarodnoj konkurentosposobnosti: zarubezhnyj 
opyt. Gumanitarnye issledovanija v Vostochnoj Sibiri i na Dalnem Vostoke, 4, 60-64. Retrieved from <http://bit.do/ fFZ9 $>$

Kuznecova, V. V., Mashkina, O. A. (2009). Vysshaja shkola KNR: uspehi, problemy, reshenija. Jekonomika obrazovanija, 2, 64-82.

Lokshyna, O.

(2014). Profesionalizatsiia porivnialnoi pedahohiky v Ukraini: zdobutky i vyklyky u vymiri pedahohichnoi komparatyvistyky u zarubizhzhi. Porivnialno-pedahohichni studii, 6, 5-12. Retrieved from <https:// core.ac.uk/down load/pdf/ 32309643.pdf $>$

Luniachek, V. E. (2017). Pidvyshchennia kvalifikatsii pedahohichnykh pratsivnykiv: tendentsii $\mathrm{v}$ umovakh hlobalizatsii. Zasoby navchalnoi ta naukovodoslidnoi roboty, 48, 5-24.

Luniachek, V. E. (2009). Rozvytok systemy vyshchoi osvity u SShA v umovakh detsentralizatsii vlady. Problemy suchasnoi pedahohichnoi osvity, 21, 5, 34- 46.

Melnykova, O. O. (2020). Rozvytok fakhovoi kompetentnosti vykladachiv VNZ u systemi pisliadyplomnoi osvity Velykoi Brytanii, 15. Retrieved from $<$ http://enpuir.npu.edu.ua/bitstream/ 123456789/4763/1/Melnykova.pdf>

Postryhach, N. O. (2013). Pidvyshchennia kvalifikatsii uchyteliv u yevropeiskomu rehioni: problemy, perspektyvy. Psykholohopedahohichni nauky, 3, 55-60.

Prykhodkina, N. (2013). Osoblyvosti profesiino-pedahohichnoi pidhotovky vykladacha vyshchoi shkoly SShA u systemi pidvyshchennia kvalifikatsii. Nova pedahohichna dumka, 3, 115-118. Retrieved from <http://nbuv.gov.ua/ UJRN/Npd_2013_3_35>

Prezydent Ukrainy. (2017). Zakon Ukrainy Pro osvitu vid 05.09.2017 № 2145-VIII [Law of Ukraine dated 05.09.2017 No. 2145-VIII], Vidomosti Verkhovnoi Rady, 38-39, 380. Retrieved from < http://ru.osvita.ua/legislation/ law/2231/>

Terenko, O. O. (2018). Orhanizatsiino-pedahohichni zasady osvity doroslykh u SShA i Kanadi.
Pedahohika i psykholohiia, 4, 20-27.

Chzhan, Lun. (2017). Osobystisnoprofesiinyi rozvytok uchyteliv u systemi bezperervnoi pedahohichnoi osvity Kytaiskoi Narodnoi Respubliky, Kand.ped.n. thesis, Kharkivskyi natsionalnyi pedahohichnyi universytet imeni H.S. Skovorody, Kharkiv.

Advance Higher Education/ (2020). Retrieved from $<$ http://bit.do/fF2bQ $>$

Annual Report. CTL. Office of the Provost. (2020). Retrieved from $<$ http:/ /bit.do/fF2bT>

Association of American Colleges \& Universities. (2020). Retrieved from $<$ http://bit.do/fF2bW $>$

Cambridge Center for Teaching and Learning. (2020). Retrieved from $<$ https://www.cctl.cam.ac.uk/aboutcctl>

Centra, J. A. (1989). Faculty evaluation and faculty development in higher education, in Smart JC (ed.), Higher education: handbook of theory and research, $\mathrm{V}$.

Columbia university. Center for Teaching and Learning (CTL). (2020). Retrieved from <https:// ctl.columbia.edu/

Donald, J. G., Shore, B. M. (1976). Annotated index to pedagogical services in Canadian colleges and universities, Centre for Learning and Development, McGill University, Montreal.

Faculty ofEducation Beijing Normal University. (2020). Institute for Teacher Education n. d. Retrieved from $<$ https:/ /fe.english.bnu.edu.cn/t003-c-1 52.htm>

L'annuaire des INSPE (Instituts Nationaux Superieurs du Professorat et de l'Education). (2020). Retrieved from $<$ http://bit.do/fF2cu>

Le Reseau National Des ESPE Devient Le Reseau Des INSPE n.d. (2020). Retrieved from <http:// www.reseau-espe.fr/>

Lin, J., Wu, Y. (2011). Analysis of the needs of academic staff for professional development in regular universities and colleges and the infl uential factors: based on the survey in universities and colleges in Beijing (in Chinese). Journal of Educational Studies, 7 (3), 92-104.
Li, B., Li, K., Pu, Y. (2012). The knowledge structure of the college teachers (in Chinese). University Education Science, 4, 114-118.

Lunyachek, V. (2011). Problems of the Education System Development of Ukraine in Times of Crisis. Public policy and administration, 10 (1), $67-$ 79.

Lunyachek, V. (2017). The PostSoviet Syndrome of Ukrainian Education: Administrative Issues. Public policy and administration, 16, 81-90.

Mohrman, K., Geng, Y., Wang, Y. (2020). Faculty life in China. Retrieved from <http://www.nea.org/assets/docs/ HE/H-Mohrman_28Feb11_p83 100.pdf $>$

The Oxford Learning Institute. (2019). Retrieved from <https:// pod.admin.ox.ac.uk/oxford-learninginstitute-change>

The University of Waterloo. Center for Teaching Exellence n. d. (2020). Retrieved from <https:/uwaterloo.ca/ centre-for-teaching-excellence/>

University of Plymout n.d. (2020). Retrieved from <https:// www.plymouth.ac.uk/research/ institutes/pedagogic/cpd>

The University of Sydney becomes an HEA Strategic Partner n. d. (2020). Retrieved from $<$ http://bit.do/fF2c4 $>$

The University of Toronto. Faculty of Medicine. Faculty Development n. d. (2020). Retrieved from $<$ https:// www.cpd.utoronto.ca/educators/ faculty-development/>

UNESCO Institute for Lifelong Learning n. d. (2020). Retrieved from $<$ https://uil.unesco.org/>

Stanford. (2020). Center for Teaching and Learning (CTL). Retrieved from <https:// ctl.stanford.edu/>

The UK Professional Standards Framework for teaching and supporting learning in higher education. (2011). Retrieved from $<$ http://bit.do/fF $2 \mathrm{cY}>$

Weiterbildung f?r Lehrende an Hochschulen n. d. (2020). Retrieved from $<$ https://www.hdw-nrw.de/ $>$

Стаття надійшла 4.04.2020 p. 